TAHKIM, Jurnal Peradaban dan Hukum Islam. Vol.4 No.l (Maret, 202l) | ISSN : 2597-7962

\title{
ISLAM DAN GENDER: RELEVANSI PEMBAHARUAN ISLAM BIDANG KELUARGA DAN TUNTUTAN EGALITER
}

\author{
Suyuti Dahlan Rifa'i, Hijriatu Sakinah \\ Universitas Islam Negeri Sunan Kalijaga Yogyakarta \\ suyutirifai99@gmail.com
}

\begin{abstract}
ABSTRAK
Hukum Jahiliyyah pra-Islam bersifat patriarki, diskriminatif, dan zalim. Islam hadir merubah bahkan menghapus tradisi-tradisi buruk yang telah mengakar kuat dalam masyarakat pra-Islam. Karakter Islam bertolak belakangan dengan tradisi Jahiliyyah. Islam menjunjung tinggi persamaan dan kesetaraan sebagaimana tertuang dalam alQuran dan hadis. Metode yang digunakan adalah penelitian kepustakaan (library research) dengan menggunakan pendekatan kualitatif. Data-data yang diperoleh dianalisis menggunakan teknik deskriptif analisis. Secara teoritis al-Quran mengandung prinsip kesetaran antara laki-laki dan perempuan, kelahiran Islam sebagai rahmatan lil alamin memberikan hak-hak dalam perkawinan, mahar, poligami dan waris bagi perempuan, sehingga Islam mengubah budaya patriarki (otoritas suami) menjadi peradaban yang bersifat egaliter. Pembaharuan Islam di bidang keluarga tersebut sejalan dengan tuntutan egaliter antara perempuan dan laki-laki (suami dan istri).
\end{abstract}

\section{Kata Kunci : Pembaharuan Islam, Keluarga, Egaliter, Suami, Istri.}

\begin{abstract}
The pre-Islamic law was patriarchy, discriminatory, and despotic. Islam was present to change and even expunge an immoral traditions that were existing in past era. Islamic characters contradicted to the ignorance tradition. Islam upholds equality as stated in the Quran and hadith. The method used is library research and using a qualitative approach. The data obtained were analyzed using descriptive analysis techniques. Theoretically, the Qoran contains the principle of equality between men and women, the come of Islam as rahmatan lil alamin provides rights in marriage and inheritance for women. Thus, Islam changed the patriarchal culture (husband's authority) into an egalitarianism. Islamic reform in the family sector is regarded with egalitarian demands between women and men (husband and wife).
\end{abstract}

Keywords: Islamic Reform, Family, Egality, Husband, Wife. 
TAHKIM, Jurnal Peradaban dan Hukum Islam. Vol.4 No.l (Maret, 202I) | ISSN : 2597-7962

\section{A. PENDAHULUAN}

Islam pertama kali diwahyukan kepada Nabi Muhammad SAW (Selanjutnya di sebut Nabi). Pada hari Senin tanggal 17 Ramadhan (6 Agustus 610 M) di gua Hira ${ }^{1}$. Dalam peristiwa tersebut malaikat Jibril hadir di hadapan Nabi, kemudian ia memerintahkan Nabi untuk membaca wahyu sebanyak 3 (tiga) kali, meskipun Nabi Muhammad mengatakan bahwa ia tidak dapat membaca, namun malaikat Jibril tetap bersikeras memerintahkan Nabi Muhammad untuk membaca wahyu yang disampaikan. Hingga kemuadian malaikat Jibril mengajarinya. ${ }^{2}$ Inilah langkah awal bagi Nabi dalam mengemban misi risalah kenabiannya, dimana, Allah swt telah memilihnya untuk suatu tujuan yang khusus sebagai seorang. Nabi. Syariat Islam yang dikokoh dengan kedua sumber pokoknya Al-Quran dan Sunnah hadir selain untuk mengokohkan tauhid juga salah satunya untuk menyempurnakan sekaligus menghapus kebiasaam-kebiasaan buruk, zaman Jahiliyyah (pra-Islam). ${ }^{3}$ Islam di awal kemunculan dihadapkan pada keadaan terbelakang baik mental mapun intelektual, salah-satunya adalah kebiasaan dan praktik buruk dalam pernikahan.

Pada masa pra-Islam, konsep pernikahan kebanyakan sangat merugikan posisi perempuan. Kaum perempuan hanya dianggap sebagai komoditi yang dengan mudah dapat diperdagangkan atau diwariskan tanpa adanya persetujuan dari perempuan sehingga kedudukannya tidak dihargai. Selain itu, kelahiran perempuan menjadi aib yang sangat memalukan bagi keluarga, atau menguburkannya hidup-hidup dalam tanah, ditambah lagi, permasalahan waris, tradisi umat pra-Islam mengekang perempuan dan anak yang belum dewasa untuk mendapat warisan. ${ }^{4}$ keadaan ini bahkan tergambar dalam QS. An-Nahl, sebagai berikut:

${ }^{1}$ Muhammad Husain, Sejarah Hidup Muhammad, (Jakarta: Pustaka Litera Antar Nusa, 2003), hlm. 79.

${ }^{2}$ Akbar S. Ahmed, Rekonstruksi Sejarah Islam, (Yogyakarta: Fajar Pustaka Baru, 2002), hlm. 2627.

3 Kata Jahiliyyah, berasal dari kata ja-ha-la dalam bahasa Arab berarti kebodohan, kata ini diistilahkan untuk kaum musyrikin yang hidup sebelum kehadiran Islam, sebuah terma yang dimaknai sikap kaum jahiliyyah yang menolak kenenaran terhadap Islam. Lihat Luthviyah Romziyana, "Pandangan al-Qur'an Tentang Makna jahiliyah Perspektif Semantik", Mutawatir: Jurnal Keilmuan Tafsir Hadis, Vol. 4, No. 1, (Juni, 2014), hlm. 122-123

4 Abd. Rahim Amin, "Hukum Islam dan Transformasi Sosial Masyarakat Jahiliyyah: (Studi Historis tentang Karakter Egaliter Hukum Islam)", Jurnal Hukum Diktum Madrasah Aliyah Negeri (Man) 3 Makassar, Vol. 10, No. 1 (Januari, 2012), hlm. 2. 


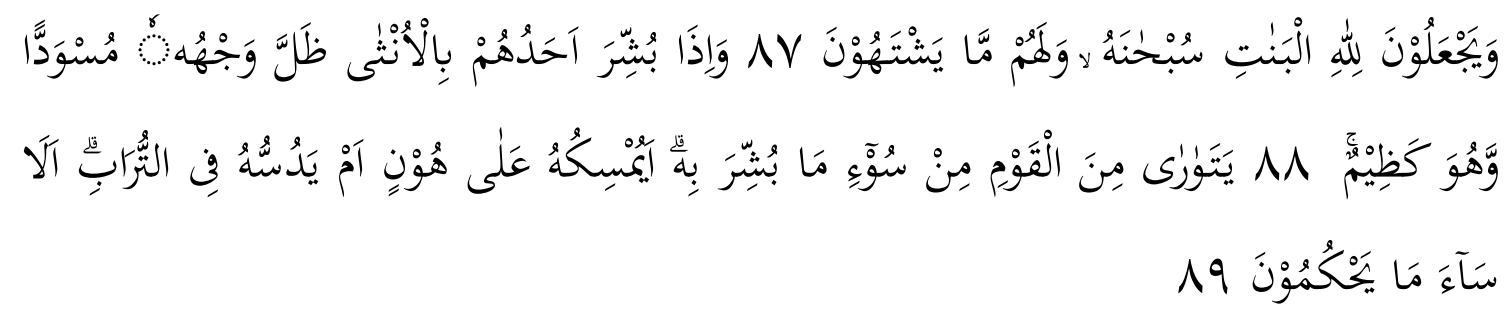

"Dan mereka menetapkan bagi anak-anak perempuan. Maha Suci Allah, sedang untuk mereka sendiri (mereka tetapkan) apa yang mereka sukai (yaitu anak-anak laki-laki). Dan apabila seseorang dari mereka diberi kabar dengan (kelahiran) anak perempuan, hitamlah (merah padamlah) mukanya, dan dia sangat marah. Ia menyembunyikan dirinya dari orang banyak, disebabkan buruknya berita yang disampaikan kepadanya. Apakah dia akan memeliharanya dengan menanggung kehinaan ataukah akan menguburnya kedalam tanah (hidup-hidup) ? ketahuilah, alangkah buruknya apa yang mereka tetapkan itu".

Demikian Tradisi-tradisi buruk pra-Islam yang menempatkan perempuan pada posisi yang tertindas dalam pernikahan. ${ }^{6}$ Dalam lingkungan masyarakat ini, menyandarkan peradabannya pada ajaran-ajaran umat terdahulu, ajaran yang sudah pasti menyekutukan Allah. Sampai pada waktunya, Islam mulai dinyatakan secara terangterangan melalui jalan dakwah yang dilakukan secara terbuka, meskipun disisi lain, kehadiran Islam tersebut banyak ditentang dan ditolak. Sikap permusuhan semakin serius ketika Nabi melarang dan menyerukan agar bangsa Arab pra-Islam meninggalkan kebiasaan Jahiliyyahnya. ${ }^{7}$

Larangan praktik pembunuhan anak perempuan seacara hidup-hidup dan merendahkan perempuan dalam status pernikahan adalah bukti keberhasilan dakwan Nabi. Perempuan dalam pandagan Islam sangat mulia kedudukannya, perempuan diberikan hak waris, sehingga baik perempuan dan laki-laki sama-sama mendapatikan warisan, ini dilakukan demi mengangkat perempuan, diberikan hak penuh, menyelamatkannya dari keterpurukan, diskriminasi dan intimidasi, tidak hanya itu, seorang ibu lebih dimuliakan dan didahulukan disbanding ayah, dimana ketaatan kepada ibu 3 (tiga) kali lebih utama dibanding ayah. Bahkan perempuan diangkat Kedudukannya sampai menjadi bagian dari nama surat dalam al-Quran yaitu, "An-

\footnotetext{
${ }^{5}$ QS. An-Nahl: 57-59.

${ }^{6}$ Hendri Hermawan A. dkk, "Kewenangan dan Kedudukan Perempuan dalam Perspektif Gender: Suatu Analisis Tinjauan Historis", Marwah, Vol. 17, No. 1 (2018), hlm. 44-46.

${ }^{7}$ Muhammad Husain, Sejarah Hidup Muhammad, (Jakarta: Tintamas, 2003), hlm.1-3.
} 
TAHKIM, Jurnal Peradaban dan Hukum Islam. Vol.4 No.l (Maret, 202I) | ISSN : 2597-7962

Nisa" yang memiliki arti perempuan. Dalam ini menunjukkan Islam menghargai manusia dan tidak menetapkan keburukan hanya dengan bersandar pada gender.

Pada hakikatnya Syariat yang terkandung dalam Islam bersifat universal. Ini memberi tendensi bahwa Islam dapat merangkum semua aspek, selalu berlaku setiap zaman dan orisinil walaupun melintasi peradaban. Di dalamnya ada dimensi hukum yang menuntut pembaharuan dan modifikasi, oleh sebab itu, keuniversalitas Islam teruji oleh waktu. ${ }^{8}$ Sebagai konsekuensi dari tuntutan tersebut, Segala tradisi-tradisi maupun sistem sosial jahiliyyah kemudian dirombak bahkan dihapus oleh Islam. Dalam Islam setiap aspek kehidupan diatur dengan komplit dan sempurna, sehingga hukumhukumnya dengan mudah diterima nalar manusia.

Dewasa ini, tidak asing didengar tuntutan-tuntutan yang menyuarakan pemikiran tentang menyetarakan antara laki-laki dan perempuan (prinsip egaliter) ${ }^{9}$. Isu ini sebagai respon terhadap budaya patriakhi, sekaligus sangat erat hubungannya dengan prinsip egaliter, lebih luas lagi, bahwa prinsip egaliter ini mengusung konsep kesetaraan manusia tanpa melihat agama, etnis, ras, suku, budaya, bahkan kelas sosialnya. Akan tetapi, unsur yang dipandang harus berdasarkan prestasinya. Dari sini baik perempuan maupun laki-laki memiki kesempatan yang sama dalam dalam ajang pembuktian diri.

Peningkatan partisipasi perempuan dalam berbagai aspek memberikan celah tersendri bagi kaum perempuan untuk semakin giat menunjukkan kemampuannya. Sejarah pra-Islam yang pernah menempatkan perempuan tanpa hak, jika dibanding dengan keadaan abad ini tentu sangan bertolak belakang. Prinsip Egaliter Bahkan telah mulai mempengaruh konteks "suami dan istri", sedangkan secara tradisional, terdapat penekanan kedudukan antara perempuan dan laki-laki dalam rumah tangga (suami dan istri). sebagian memahami bahwa laki-laki lebih unggul dari perempuan, sebagian lain lagi memahami perempuan juga dimuliakan dari laki, oleh karena itu tulisan-tulisan dalam diskusi ini, menjadi topik yang menarik utuk dikaji.

Sejauh penelusuran penulis, Ada beberapa penelitian dan tulisan yang telah membahas seputar tentan pembaharuan Islam, egaliter dan suami, istri. Tulisan pertama

\footnotetext{
${ }^{8}$ Munawir Haris, "Pembaharuan atas Hukum Keluarga di Indonesia: Satu Tinjauan Sosiologis", Ulumuna. STAIN Sorong Papua Barat, Vol. 19, No. 1 (June) 2015 , hlm. 137.

${ }^{9}$ Egaliter berasal dari Bahasa prancis, egal, egalitaire, egalite yang berarti sama, tidak ada perbedaan, memiliki persamaan ha kantar manusia, yang kemudian diserap dalam Bahasa Indonesia menjadi egaliter yang berarti sederajat. (Departemen Pendidikan dan Kebudayaan, Kamus Besar Bahasa Indonesia, (Jakarta: Balai Pustaka, 1989), hlm. 285.
} 
TAHKIM, Jurnal Peradaban dan Hukum Islam. Vol.4 No.l (Maret, 202I) | ISSN : 2597-7962

dari Hendri Hermawan A. dkk, "Kewenangan dan Kedudukan Perempuan dalam Perspektif Gender: Suatu Analisis Tinjauan Historis". ${ }^{10}$ Dalam jurnal ini, penulis berusaha mendeskripsikan tentang kewenangan dan kedudukan perempuan dalam perspektif gender dengan analisis berdasarkan pendekatan historis, pada zaman Islam jahiliyyah, kaum perempuan didiskriminasi dari berbagai aspek sedangkan laki-laki, mereka ditempatkan pada posisi yang superior, kemudian Islam datang menebarkan prinsip-prinsip yang mengangkat tema kesetaraan dan persamaan antara laki-laki dan perempuan, Islam mengajari manusia hanya akan dininilai berdasarkan ketakwaannya. Tulisan ini berbeda dengan judul paper penulis, dimana penulis tidak hanya mengkhususkan pembahasan pada ranah pembaharuan Islam dibidang keluarga tetappi, juga memaparkan bagaimana relevansisnya dengan tuntutan egaliter terhadap suami dan istri.

Penelitan selanjutnya adalah skripsi yang berasal dari Sri Wahyuni, dengan judul "Pembaharuan Hukum Keluarga Islam di Negara-Negara Muslim" yang pada pokonya membahas, metode pembaharuan hukum Islam menggunakan metode intra-doctrinal dan extra-diktrinal reform, regulasi dan kodifikasi, selain itu, tulisan ini juga memaparkan terdapat tiga tipologi negara Muslim berdasarkan pembaharuan hukum Islam yang, yaitu negara Muslim yang menggunakanhukum Islam sebagaimana dalam (fiqh) tradisional, negara muslim yang mengadopsi hukum Barat, dan negara Muslim yang menerapkan hukum Islam dengan menggunakan metode dan prosedur layaknya hukum Barat. Adapun yang menjadi pokok-pokok pembaharuan hukum keluarga oleh negara-negara Muslim ini adalah di antaranya adalah terkait, adanya pembatasan usia minimal dibolehkannya mengadakan perkawinan, diberlakukan kontrol terhadap izin poligami, dalam hal ceraian, suami dan isteri harus melalui prosedur pengadilan, sedangkan terhadap persoalan waris, terdapat pengaturan wasiat wajibah. perbedaanya dengan tema yang ditulis penulis adalah, bahwa materi pembaharuan penulis merujuk pada pembaharuan awal kehadiran Islam pada zaman Jahiliyyah, ini berbeda dari pembaharuan dalam skripsi oleh Sri W. yang memaparkan pembaharuan yang dipenaruhi tuntutan zaman yang telah dilegitimasi negara. ${ }^{11}$

\footnotetext{
${ }^{10}$ Hendri Hermawan A. dkk, "Kewenangan dan Kedudukan Perempuan dalam Perspektif ...., hlm. 43.

${ }^{11}$ Sri Wahyuni, "Pembaharuan Hukum Keluarga Islam di Negara-Negara Muslim", Al-ahwal, Vol. 6, No. 2 (2013), hlm. 212.
} 
TAHKIM, Jurnal Peradaban dan Hukum Islam. Vol.4 No.l (Maret, 202I) | ISSN : 2597-7962

Terakhir, karya dengan judul "Hukum Islam Sebagai Revolusioner dan Egaliter dalam Kehidupan Sosial" Oleh Arzam, dalam tulisan ini mengambarkan Hukum Jahiliyyah pra Islam yang rasialis, feodal dan patriarkis, Islam lahir kental dengan karakter yang membangun prinsip kesetaraan, ini bertolak belakang dengan hukum Jahiliyyah. Hukum-hukum Islam diperkenalkan dan dipraktekkan melalui perilaku Nabi Muhamad Saw beserta para pengikutnya. Penolakan kaum Quraisy terhadap Islam sangat berkaitan erat dengan aspek keagamaan dan aspek sosial. Kehadiran Islam berbeda dengan hukum-hukum jahiliyyah. Islam Memiliki karakter egaliter dan hal tersebut merupakan sebuah perubahan social dari hukum Jahiliyyah yang tidak egaliter menjadi hukum Islam yang egaliter. ${ }^{12}$

Tulisan ini berangkat pada sebuah pemahaman bahwa Islam sebagai Rahmatan lil 'alamin (rahmat bagi semesta), keberadaan Islam telah banyak mengubah tatanan sosial dalam stigma manusia, dalam konteks ini paling tidak ada beberapa sub bahasan yang akan menjadi pokok penulisan yaitu konsep pembaharuan Islam di bidang keluarga dan keluarga pra-Islam, pokok-pokok pembaharuan bidang keluarga oleh Islam dan relevansi konsep kesetaraan laki-laki dan perempuan (suami dan istri) dengan pokok-pokok pembaharuan dibidang keluarga.

\section{B. METODE PENELITIAN}

Metode yang digunakan adalah penelitian kepustakaan (library research), yaitu melakukan dengan metode membaca, menelaah dan memeriksa bahan kepustakaan yang terdapat di dalam perpustakan atau di luar perpustakaan. ${ }^{13}$ Kemudian dengan menggunakan pendekatan kualitatif, yaitu penelitian tanpa menggunakan perhitungan dengan tujuan untuk mendeskripsikan atau menganalisis suatu peristiwa secara kompleks. ${ }^{14}$ Data-data yang digunakan dalam penelitian ini berupa al-Quran dan Sunnah serta sumber lainnya berupa buku, jurnal, dan sumber-sumber lain yang relevan

\footnotetext{
12 Arzam. "Hukum Islam Sebagai Revolusioner dan Egaliter dalam Kehidupan Sosial", Islamika, Vol. 14, No. 1 (2014), hlm. 1-2.

13 Dudung Abdurahman, Pengantar Metode Penelitian, (Yogyakarta: Kurnia Kalam Semesta, 2003), hlm 7.

${ }^{14}$ Lexi J Moleong, Metode Penelitian Kualitatif, (Bandung: PT. Remaja Rosda Karya, 2002), hlm. 2.
} 
dengan penelitian ini. Data-data yang ada tersebut dianalisis menggunakan teknik deskriptif analisis.

\section{PEMBAHASAN}

\section{Pembaharuan Islam di Bidang Keluarga}

Secara Bahasa, pembaharuan berasal dari kata baharu, adalah sesuatu yang sebelumnya tidak ada. Kemudian pembaharuan dalam kaca mata Islam adalah berkaitan dengan sesuatu yang ada sebelumnya kemudian berubah berkaitan dengan Islam. ${ }^{15}$ Dalam hal ini, pembaharuan pembaharuan merupakan suatu proses yang menjadikan sesuatu yang telah usang menjadi baru kembali, pembaharuan Islam adalah proses pemurnian di mana. konsep asalnya dipahami dan ditafsirkan sehingga lebih jelas, kemudian diimplementasikan oleh masyarakart pada masanya.

Kedatangan Islam dengan membawa perubahan dan pembaharuan di berbagai bidang termaskud aturan hidup dan akhlak, Islam yang mulai meluas secara perlahan diterima oleh kalangan masyarakat arab, hal tersebut disebabkan karena, Islam lebih relevan dengan kehidupan mereka sehari-hari. Implikasinya adalah tradisi-tradisi jahiliyyah mulai terkikis dan tergerus karena keberadaan Islam.

Islam hadir di kalangan masyarakat arab tidak serta merta langsung menghilangkan sema kebiasaan dan sistem sebelumnya. seorang pemikir asal mesir, Khalil Abdul Karim, menyatakan bahwa banyak hal yang terkait dengan tradisi masyarakat arab zaman Jahiliyyah, lalu kemudian Islam mengadopsi dan diajadikan bagian dari doktrin keagamaan. ${ }^{16}$ Sedangkan Abu Hapsin, bahwa "Al-Quran maupun ijtihat Nabi Muhammad Saw tidak mengahapus semua tradisi dan budaya yang telah mengakar kuat dalam masyarakata jahiliyyah namun Nabi justru melakukan akulturasi dan inkulturasi, perubahan-perubahan oleh Islam, ada yang menerima secara total, ada yang diterima melalui moodoifikasi terlebih dahulu, ada juga yang secara tegas ditolak dengan budaya setempat, sehingga upaya-upaya pendekatan Islam memungkinakan penerimaan oleh masyarakat arab, terhadap persoalan perdata dan pidana tidak lepas

\footnotetext{
15 Bustami Muhammad Said, Gerakan Pembaharuan Agama Antara Modernisme dan Tajdiduddin, (Bekasi: Wacana Lajuardi, 1995), hlm. 29.

${ }^{16} \mathrm{http} / / \mathrm{www} /$ isjd.pdii.lipi,go,id (Mochammad Mu'izzuddin, "kontribusi dialek quraisy dan dialek tamim terhadap Bahasa arab fushha (kajian sosio-psikolinguistik)”, diakses pukul 14:00 WIB tanggal 12 Desember 2020.
} 
TAHKIM, Jurnal Peradaban dan Hukum Islam. Vol.4 No.l (Maret, 2021) | ISSN : 2597-7962

(berkelanjutan) dari hukum-hukum yang telah hidup sebelumnya namun untuk persoalan Muamalah dan pranata sosial kebanyak diterima menjadi bagian Islam. ${ }^{17}$

Pada zaman pra-Islam, keberadaan perempuan sangat tidak dihormati, dianggap hina, tidak diberikan hak dalam bentuk apapun, dalam sejarah perempuan ditempatkan pada kedudukan yang serendah-rendanhnya dan dijadikan sebagai objek penindasan dan budak hawa nafsu. Apabila wanita-wanita dinikahi, kemudian suaminya tersebut meninggal dunia, maka wanita-wanita (istri) tersebut dapat diwarisi oleh anak-anaknya , tidak ada batasan dalam memiliki istri (poligami), seorang suami dengan bebas menyerahkan istri kepada laki-laki lain selanjutnya, terhadap kelahiran seorang anak, bila dalam satu keluarga mendapati kehilan anak laki-laki maka keluarganya akan bergembira sekaligus bangga, namun jika yang dilahirkan adalah anak perempuan, sebaliknya, keluarganya akan bersedih, kecewa dan malu, sebab, kelahiran anak perempuan dipandang sebagai aib bagi keluarganya, bahkan masyarakat jahiliyyah tidak segan-segan menguburkan bayi perempuan hidup-hidup, karena hanya akan melemahkan keluarganya dimata suku lain. Hal ini telah digambarkan dalam alQura'an, sebagai berikut:

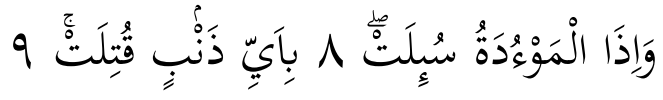

"Dan apabila bayi-bayi perempuan yang dikubur hidup-hidup ditanya, karena dosa apakah ia dibunuh". ${ }^{18}$

Wanita sebelum datangnya Islam hidup dalam pusara kehinaan dan kenistaan Meskipun terdapat larangan terhadap praktik jahiliyyah tersebut dari beberapa kelompok, namun suaranya minoritas sehingga praktik yang telah mengakar kuat tersebut terus belaku dikalangan rakyat arab pra-Islam. Budaya arab jahiliyyah mengatur perempuan tidak berhak memperoleh warisan. Kondisi sosial masyarakat Arab pra-Islam sangat rapuh dan tanpa arah, para perempuan diperlakukan seperti benda, diperjual-belikan. Segala keburukan moral peradaban jahiliyyah tersebut berubah setelah Nabi Saw dengan kemuliaan ahlaknya mengubah perbudakan, melenyapkan kemusrikan.

\footnotetext{
${ }^{17}$ Abu Hapsin, "Islam dan Budaya Lokal: Ketegangan antara Problem Pendekatan dan Kearifan Lokal Masyarakat Jawa", dalam http//www/kemenag,go.idacis1 filedokumene2AbuHapsin.pdf. diakses pada 12 Desember 2020.

${ }^{18}$ QS: At-Takwir: 8-9.
} 
TAHKIM, Jurnal Peradaban dan Hukum Islam. Vol.4 No.l (Maret, 202I) | ISSN : 2597-7962

Islam menghapus segala bentuk perkawinan yang bertentangan dengan syariat Islam, segala kezaliman dihapuskan, Islam Mengembalikan kedudukan perempuan dengan memualikannnya sekaligus menjadikan perempuan sejajar dengan laki-laki, dengan pengecualian terhadap perkara-perkara yang diperuntukkan untuk laki-laki. penghormatan terhadap kedudukan perempuan dalam Islam dengan cara, membenarkan perkawinan antara seorang laki-laki dan perempuan yang tidak terhalang oleh ketentuan syar'i, proses perkawinan diawali dengan peminangan, kemudian memberikan mahar hingga ijab-qabul, Islam menetang segala bentuk penindasan, kezaliman dan ketidakadilan.

Kemudian persoalan Kewarisan, Pada masa awal Islam. Perombakan aturan kewarisan tidak mudah dilakukan, sampai turun ayat yang menegaskan para lelaki dan perempuan memperoleh harta warisan sebagaimana firman allah dalam al-Quran, sebagai berikut:

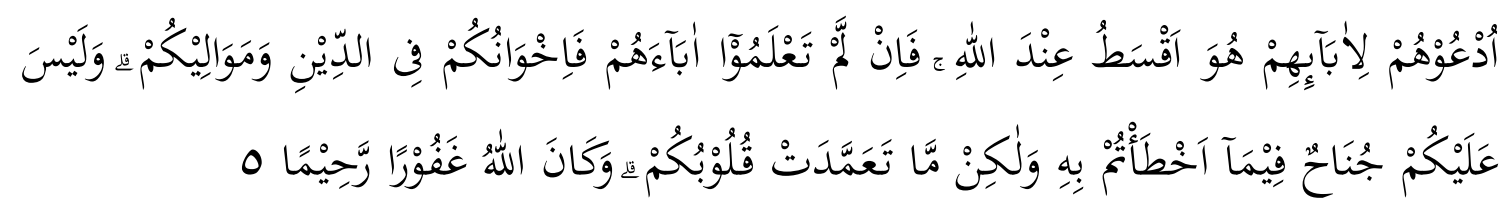

"bagi laki-laki ada hak bagian dari harta peninggalan kedua orang tua dan kerabatnya, dan bagi perempuan ada hak bagian (pula) dari harta peninggalan kedua orang tua dan kerabatnya, baik sedikit atau banyak, menurut bagian yang telah ditetapkan". 19

Dengan diturunkan ayat tersebut maka hapuslah ketentuan yang melarang hak waris terhadap perempuan dan anak. Pada masa awal Islam, seseorang dimungkinakan memperoleh warisan apabila ada pertalian kerabat, adanya pengangkatan anak, adanya hijrah, dan adanya ikatan persaudaraan. ${ }^{20}$

\section{Pokok-Pokok Pembaharuan Islam di Bidang Keluarga}

Setelah memaparkan kondisi masyarakar arab pra-Islam dan setelah kehadiran Islam, penulis merangkum beberapa poin Pokok-Pokok Pembaharuan Islam di Bidang Keluarga sebagai berikut :

${ }^{19}$ Q.S al-Ahzab (33): 5.

${ }^{20}$ Asrizal, "Peletakan Dasar-Dasar Hukum Kewarisan Islam (Tinjaun Historis atas Hukum Waris Pra dan Awal Islam)" Al-Ahwal, Vol. 9, No.1 (Juni 2016), hlm. 126-127. 
TAHKIM, Jurnal Peradaban dan Hukum Islam. Vol.4 No.l (Maret, 202I) | ISSN : 2597-7962

a. Perkawinan, kehadiran Islam di tengah-tengah bangsa arab mengubah sistem patriarki (otoritas suami), Islam dan syariatnya menghapus tradisi-tradisi buruk masyarakata jahiliyyah, perkawinan dalam Islam melalui beberapa proses, yaitu, perkawinan diawali dengan peminangan, kemudian memberikan mahar hingga ijabqabul, Islam membuat metafor sehingga keberlakuan tradisi perkawinan pra-Islam dirombak dengan syariat Islam, Islam memuliakan perempuan yang terlihat dengan ditetapkannya proses-proses perkwinan.

b. Mahar, mahar merupakan tanda kesungguhan dari seorang laki-laki untuk menikahi seorang perempuan. Rasulullah Saw bersabda "Sebaik-baiknya mahar adalah mahar yang paling mudah (ringan)". ${ }^{21}$ Mahar selanjutnya akam menjadi milik secara penuh.

c. Poligami, poligami merupakan tradisi bangsa arab pra-Islam yang kental dan kuat, dalam tradisi pra-Islam tidak ada batasan dan aturan dalam memiliki istri (poligami), sedangkna Islam meletakkan batas maksimal perkawinan dengan syarat yang ketat. Jika tidak mampu dianjurkan satu istri saja.

d. Waris, perempuan dalam pandagan Islam sangat mulia kedudukannya, perempuan diberikan hak waris, sehingga baik perempuan dan laki-laki sama-sama mendapatikan warisan.

Berbeda dengan perpektif pembaharuan Hukum Keluarga Islam oleh negaranegara muslim, dilakukan pada berbagai bidang: ${ }^{22}$

a. Usia perkawinan, beberapa negara muslim telah menetapkan batas usia untuk melangsungkan perkawinan mulai dari usia 15-18 tahun.

b. Pencaatatan perkawinan. Terdapat persamaan terkait pencatatan pekawinan dalam negara-negara muslim, dimana hukum negara mewajibkan agar melakukan penctatan perkawinan kepada lembaga yang berwenang .

c. Talak, pembaharuan hukum keluarga Islam dibidang talak dilakukan dengan menetukan bahwa talak yang diucapkan tiga kali belum dapat dianggap sebagai talak tiga, sebelum dilaksanakan prosesnya di pengadilan.

\footnotetext{
${ }^{21}$ H.R Al-Hakim: 2692.

22 Sri Wahyuni, "Pembaharuan Hukum Keluarga Islam..., hlm. 215.
} 
TAHKIM, Jurnal Peradaban dan Hukum Islam. Vol.4 No.l (Maret, 202I) | ISSN : 2597-7962

d. Poligami, hukum keluarga melakukan control terhadap persoalan poligami dengan menerapkan persyaratan yang telah ditetapkan dalam al-Quran, membuat kontrak untuk tidak melakukan pologami, control dari hukum dan pengadilan dengan mesyaratkan izin istri pertama untuk berpoligami, ada juga negara yang melarang poligami sebagaimana yang dilakukan oleh Turky, atau memberikan sanksi pidana bagi pelaku poligami.

e. Status Anak, negara-negara muslim menetapkan Anak sah adalah anak yang lahir dalam perkawinan yang sah, konsekuensi dari sahnya status kelahiran anak akan berimplikasi pada hak waris yang akan diperolehnya kelak.

\section{Relevansi Konsep Kesetaraan Laki-Laki dan Perempuan (Suami dan Istri) dengan Pokok-Pokok Pembaharuan di bidang Keluarga}

Salah satu prinsip pokok ajaran Islam adalah prinsip egaliter, prinsip ini menawarkan adanya persamaan antar manusia, baik laki-laki maupun perempuan, Allah Swt menegaskan persamaan kedudukakn perempuan dan laki-laki dalam QS. alHujuraat : 13:

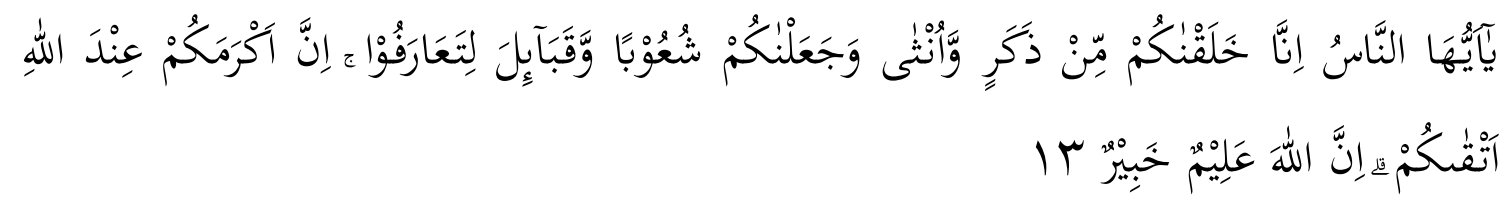

"Hai manusia sesungguhnya kami menciptakan kamu dari seorang laki-laki dan perempuan, dan menjadikan kamu berbangsa-bangsa dan bersuku-suku supaya kamu saling kenal mengenal, sesungguhnya orang yang paling mulia diantara kamu di sisi Allah adalah orang yang paling bertakwa diantara kamu”.

Secara teoritis al-Quran mengandungn prinsip kesetaran antara laki-laki dan perempuan, ayat di atas menggambarkan bahwa yang membedakan manusia hanya terletak pada tingkatan ketakwaannya. Demikian juga dalam urusan rumah tangga, dalam Islam, tidak ada alasan apapun yang distribusi beban sosial antara laki-laki dan perempuan, baik dalam ranah rumah tangga, maupun dalam lingkungan masyarakat. Kesetaraan antara laki-laki dan perempuan dapat terlihat dari hubungan kemitraan yang dibangun oleh pasanganantara suami dan istri.

Konsep kesetaraan laki-laki dan perempuan juga dapat ditemukan dalam al-Quran yang terjemahnya sebagai berikit, "Mereka (para istri) adalah pakain bagimu, dan 
TAHKIM, Jurnal Peradaban dan Hukum Islam. Vol.4 No.l (Maret, 202I) | ISSN : 2597-7962

kamupun pakaian bagi mereka". ${ }^{23}$ Ayat ini menegaskan Allah Swt memberikan penilaian yang adil, bahkan antara suami dan istri menjadi komponen yang saling membutuhkan satu sama lain. Hubungan Kemitraan antara suami dan istri tidak lain bertujuan untuk menciptakan suasana damai, adil, setara dalam keluarga. Dalam perspektif Islam, perkawinan adalah sebuah perjanjian antara dua orang yaitu suami dan istri dengan landasan kesetaraan. Seorang perempuan (istri) sederajat dengan seorang laki-laki(suami), dengan demikian hubungan suami istri adalah hubungan horizontal, untuk saling bekerjasama. ${ }^{24}$

Sehubungannya dengan pokok pembaharuan Islam di bidang keluarga, Perkawinan dalam Islam telah mengubah sistem patriarki. Sistem ini mengambil mengambil garis keturunan dari atas yang dilakukan oleh anggota-anggota dalam suatu masyarakat tertentu, keturunan dari atas tersebut melalui garis bapak, bapak dari bapak dan seterusnya berdasarkan jalur ke atas, sistem ini memberikan otoritas yang lebih kepada laki-laki/suami dibanndungkan kepada perempuan/istri. ${ }^{25}$ Kemudian Islam menghapus tradisi-tradisi buruk perkawinan masyarakata jahiliyyah, sehingga prosesi perkawinan diawali dengan peminangan, memberikan mahar hingga ijab-qabul. Prosesi ini memberi gambaran Islam membuat suatu metafor sehingga keberlakuan tradisi perkawinan pra-Islam dirombak dengan syariat Islam, Islam memuliakan perempuan yang terlihat dengan ditetapkannya proses-proses perkwinan yang ketat. Dalam hal ini, Islam memandang perkawinan hubungan seperti kontrak kepertdataan biasa, sangatlah tepat bahwa perkawinan dipandang sebagai perjanjian yang kokok atau akad yang sangat kuat, dimana dengan melakukannya memiliki makna sebagai ibadah lepada Allah Swt. ${ }^{26}$ Kemudian pada persoalan Waris, Perempuan dalam pandagan Islam sangat mulia kedudukannya, perempuan diberikan hak waris, sehingga baik perempuan dan laki-laki sama-sama mendapatikan warisan tanpa dihalangi struktur maupun sistem patriarki.

${ }^{23}$ QS.al-Baqarah: 187

${ }^{24}$ Rustam Dahar W.A.H, "Kesetaraan Laki-Laki dan Perempuan dalam Perkawinan Islam", Sawwa, Vol. 8, No.2 (April 2013), hlm.362.

${ }^{25}$ Nia Kurniati Hasibuan, "Implementasi Hukum Waris pada Masyarakat Adat Mandailing Perantauan (Studi pada Pardomuan Muslim Sumatera Utara Kota Palangka Raya)", Tahkim Jurnal Peradaban dan Hukum Islam, Vol. 3, No. 2, (Oktober, 2020), hlm. 117.

${ }^{26}$ Fahrul Fauzi, "Larangan Perkawinan Sepersusuan Ditinjau dari Perspektif Hukum Islam dan Medis", Tahkim Jurnal Peradaban dan Hukum Islam, Vol. 3, No. 2, (Oktober, 2020), hlm. 40. 
TAHKIM, Jurnal Peradaban dan Hukum Islam. Vol.4 No.l (Maret, 202I) | ISSN : 2597-7962

Prinsip keadilan berupa kesetaraan dan kesederajatan antara laki-laki dan perempuan sangat dijunjung tinggi dalam Islam, Islam tidak menganut preferensi dan diskriminasi yang menguntungkan laki-laki dan merugikan perempuan. Islam juga menggariskan prinsip kesetaraan antara laki-laki dan perempuan tetapi tidak persis sama atau identi. Kata kesetaraan (equality) telah memperoleh semacam kesucian, karena kata-kata ini mengandung keadialn tanpa adanya diskriminasi. ${ }^{27}$

Prinsip keadilan berupa kesetaraan dan kesederajatan antara laki-laki dan perempuan sangat dijunjung tinggi dalam Islam, Islam tidak menganut preferensi dan diskriminasi yang menguntungkan laki-laki dan merugikan perempuan. Islam juga menggariskan prinsip kesetaraan antara laki-laki dan perempuan tetapi tidak persis sama atau identik. Kata kesetaraan (equality) telah memperoleh semacam kesucian, karena kata-kata ini mengandung keadialn tanpa adanya diskriminasi. ${ }^{28}$

Secara tradisional, pembagian peran antara suami dan istri dalam keluarga tidak terlepas dari bagaimana pandangan masyarakat terhadap gender yang cenderung menempatkan perempuan dalam ranah domestic. suami mengemban tanggung jawab sebagai pencari nafkah, sosoknya yang kuat menjadikan posisi suami lebih dominan atas semua keputusan rumah tangga, sedangkan istri dengan sifat kasih sayang dan kelembutannya berperan mengurus rumah dan anak. Jika ditelusuri lebih lanjut, adanya kewajiban rumah tangga atau wilayah domestik seperti memasak, mencuci dan merawat anak bukanlah tanggung jawab istri. Semua merupakan tanggungj jawab suami sebagai nafkah yang harus dibayarkan.namun pada kenyataannya, istri mengambil alih seluruh pekerjaan tersebut. ${ }^{29}$

Secara rinci, Rustam Dahar Kamadi Apolo Harahap menjelaskan kajian terhadap kesetaraan laki-laki dan perempuan dalam konteks hak dan kewajiban suami dan istri $:^{30}$

a. Kesetaraan dalam menentukan pasangan

Dikalangan ulama, terdapat perbedaan pandangan tentang apakah wali merupakan sarat sah atau tidaknya perkawinan, namun, terlepas dari perdebatan tersebut pada

\footnotetext{
${ }^{27}$ Murteza M.Mutahhari, Wanita dan Hak-haknya dalam Islam. Terj, Hashem, (Bandnung: Pustaka,1985), hlm. 93.

${ }^{28}$ Ibid., hlm. 93.

${ }^{29}$ Asliah Zainal, "Egaliter Laki-laki dan Perempuan dalam Keluarga Islam: Antara Idealis dan Realitas", STAIN Sultan Qaimudddin Kendari dalam da.ristekdikti.go. hlm.12

${ }^{30}$ Rustam Dahar Kamadi, "Kesetaraan laki-laki dan perempuan dalam Hukum Perkawinan Islam”, Sawwa, IAIN Walisongo Semarang, Vol. 8, No. 2, April 2013, hlm. 363-383.
} 
TAHKIM, Jurnal Peradaban dan Hukum Islam. Vol.4 No.1 (Maret, 2021) | ISSN : 2597-7962

praktiknya di Indonesia sendiri cenderung menggunakan pendapat wali sabagai srat sahnya perkawinan yang didasarkan oleh riwayat dari Aisyah. Maka seorang wali memiliki hak "ijbar". Menurut Imam Syafi'I hak ini memberikan kesempatan kepada orang tua untuk berbuat yang terbaik bagi masa deapan anaknya, namun hak ini dibatasi dengan rambu-rambu yang tegas. Pada hakekatnya, perkawinan adalah sebuah ikatan yang memiliki dimensi, di samping hubungan individual masing-masing pasangangan. Juga dimensi sosial yang berkaitan dengan hubungan masing-masing pasangan dengan lingkungan keluarganya atau dengan masyarakat yang lebih luas. Dalam konteks ini perempuan bebas menentukan pasangan sesuai yang diharapkannya, tidak dimaknai tanpa harus seizin dan ridho walinya, sebab tidak dapat dipungkiri bahwa perkawinan akan lebih sempurna jika kebebasan tersebit dalam waktu yang bersamaan direstui oleh orang tuanya.

b. Kesetaraan fungsi dan peran

Perempuan dalam statusnya sebagai ibu sekaligus istri mempunyai hak yang cukup urgen dan mendasar dalam rumah tangganya, yaitu hak untuk memperoleh jaminan dan kesejahteraan yang dalam teminologi fiqih dikenal istilah nafkah. Hal ini berkaitan dengan peran dan fungsi berat yang dipikul perempuan dan istri sebagai pelaku reprodukasi yang tidak dapat dialihkan kepada laki-laki, selain itu, masih terdapat tugas lain seperti harus mengurus rumah tangga dan melayani suami. Sehingga tidak adil perempuan juga dibebani dengan maslaah pembiayaan hidup, maka sudah selayaknya suami yang memegang tanggung jawab nafkah. Terkait kewajiban suami dapat dilihat pengaturannya dalam Pasal 80 KHI. Menurut nasaruddin Umar sebagaimana dikutip dalam Rustam Dahar Kamadi Apollo Harahap. Islam mewajibkan suami untuk memennuhi kebutuhan istri dan anakanaknya. Tetapi ini berarti sebagai istri tidak berkewajiban secara moral membantu suami mencari nafkah. Namun peran ganda istri tidak wajib hukumnya meskipun diperbolehkan oleh agama.

c. Kesetaraan dalam menikmati hubungan seksual

Dalam perkawinan terdapat ajaran-ajaran tentang hak dan kewajiban suami dan istri, nafkah misalnya, nafkah merupakan kewajiban suami dan hak istri, sebaliknya sebagai istri berkewajiban untuk taat dan hormat kepada suami. Perbincangan tentang hak dan keawajiban suami istri ini, tidak terlepas dari bagaimana masing- 
TAHKIM, Jurnal Peradaban dan Hukum Islam. Vol.4 No.l (Maret, 202I) | ISSN : 2597-7962

masing ber-mu'asyarah secara ma'ruf. Saling menggauli dengan baik secara objektif, sehingga secara normatif kesetaraan dalam hubungan seks suami dan istri tidak terlepas dari implementasi dan perwujudan konsep mu'asyarah bi al-ma'ruf.

d. Kesetaraan dalam menentukan rekayasa genetika

Mendapatkan keturunan atau anak menjadi harapan dan kebanggaan yang bersifat naluriyah, namun dalam keadaan tertentu, ada pasangan suami dan istri yang harus memilih dan menunda kehamilan, siapakah yang berhak untuk melakukan atau tidak melakukan rekayasa keturunan (anak) itu,sejatinya juga harus setara antara laki-laki dan perempuan ( suami dan istri). Pendapat pertama oleh al-Ghazali dari kalangan mazhab Syafi'I, yang berhak memutuskan adalah suami/ayah sehingga konskuensinya istri tidak punya pilihan selain menuruti kemauan suami. Kedua pendapat daru ulama Hanafiah, yang berhak memutuskan adalah suami dan istri, alasannya karena anak tidak mungkin terwujud tanpa partisifasi keduanya. Ketiga memutuskan bukan hanya hak suami dan istri, tetapi juga umat/masyarakat dengan penekanan pada keputusan suami dan istri. Keempat yang banyak dianut oleh ahli hadis, hamper sama dengan pendapat ketiga, tetapi lebih menekankan pada kemaslahatan umat/masyarakat. Berdasarkan keempat pendapat di atas maka, tampak bahwa pendapat kedualah yang relevan dengan asaz kesetaraan antara suami istri.

e. Kesetaraan dalam pengasuhan anak

Sebagai implikasi dari peran ganda yang dilakukan oleh istri, maka munncul pertanyaan siapa yang mengurus anak? ketentuan fiqih membebaskan ibu dari kewajiban menyusui walaupun dalam realitasnya tidak mungkin seorang ibu tega untuk tidak menyusui anaknya, oleh karena itu yang menjadi stressing point, beban perawatan anak ditanggung secara kolektif kepada suami dan istri sebagai orang tua. Jika keadaan keluarga masih utuh maka pembagian kerjayang proporsional dapat dilaksankan, namun berbeda terhadap keluarga yang mengalami perceraian, KHI menjelaskan anak yang berusia di bawah 12 tahun (mumayyiz) adalah anak ibunya, namun jika anak telah mumayyiz maka anak diberikan hak untuk memilih antara ayah atau ibunya. Sedangkan biaya pemeliharaan ditanggung oleh ayahnya.

f. Hak dalam memutuskan perkawinan 
TAHKIM, Jurnal Peradaban dan Hukum Islam. Vol.4 No.1 (Maret, 2021) | ISSN : 2597-7962

Dalam lintasan sejarah, perkembangan hukum Islam tentang talak ditentukan nuktah merah bahwa hak talak bukanlah hak mutlak bagi suami, Islam telah memberikan hak kepada perempuan untuk menceraikan suaminya yang dikenal istilah khulu' yang secara harfiah berarti melepas dalam lingkup Peradilan Agama dikenla istilah cerai gugat.

Ketika berbicara tetang suami dan istri, konsep keluarga Islam, tidak ada perbedaan medalam antara suami dan istri, diantara keduanya terjalin hubungan kemitrasejajaran. Bukan hubungan struktural layaknya atasan dan bawahan, melainkan merupakan hubungan fungsional yang saling membutuhkan berbentuk horizontal tanpa mendominasi dan didominasi. Antara suami dan istri sama-sama memiliki hak dan kewajiban. $^{31}$

Namun penting dipahami bahwa apa yang dihasilkan pada zaman Nabi Saw, tentang hak-hak perempuan dibidang keluarga merupakan usaha pembebasan posisi perempuan, dengan demikian dapat dikatakan Islam merupakan agama yang memuliakan perempuan begitu juga dengan laki-laki memiliki kedudukan yang sama. Islam memberikan perhatian yang besar terhadap kerangka keluarga mengenai hak-hak maupun kewajiban yang dilekatkan kepada laki-laki dan perempuan (suami dan istri) yang diarahkan menuju keluarga yang sakinah, mawaddah, warahmah dan susana yang harmonis.

Demikian sejarah pra-Islam memperlakukan wanita dalam posisi rendah yang dapat diwariskan. Kestaraan peran antara suami dan istri yang telah dinikmati umat saat ini tidak terlepas dari sejarah perjalanan dakwah nabi dalam mengubah tatanan sosial zaman jahilyyah, tidak ada lagi praktik penguburan anak perempuan secara hiduphidup, sebab Islam telah menekankan prinsip kestaraan antara perempuan dan laki-laki (suami dan istri).

\section{SIMPULAN}

Dari pembahasan tentang Islam dan Gender: Kajian Atas Relevansi Pembaharuan Islam Bidang Keluarga dan Tuntutan Egaliter Laki-Laki Dan Perempuan, maka dapat ditarik poin penting, pertama Konsep Pra-Islam dan setelah Pembaharuan Islam di Bidang Keluarga, bahwa Sebelum Islam datang, masyarakat arab berada pada fase yang

\footnotetext{
${ }^{31}$ Fatimah Zuhra ,"Relasi Suami dan Istri dalam Keluarga Muslim Menurut Konsep Al-Quran", Analytica Islamimica, Vol. 2, No. 1 (2013), hlm. 190.
} 
TAHKIM, Jurnal Peradaban dan Hukum Islam. Vol.4 No.l (Maret, 202I) | ISSN : 2597-7962

tidak memiliki nilai dan moral. Bangsa arab memiliki kebiasaan buruk seperti, meminum minuman keras, berjudi, menyembah berhala, penindasan terhadap kaum yang lemah, dan diskriminasi terhadap perempuan. Kehadiran Islam membawa perubahan dan pembaharuan pada berbagai aspek, Islam menciptakan atmosfer baru di bidang keluarga, seperti pembaharuan di bidang pernikahan dan waris. Kedua PokokPokok Pembaharuan Islam di Bidang Keluarga diantaranya : Perkawinan, Mahar Poligami, Waris Berbeda dengan perpektif pembaharuan Hukum Keluarga Islam oleh negara-negara muslim dilakukan pada berbagai bidang : Usia perkawinan, Pencatatan perkawinan, Talak, Poligami, dan Status Anak. Ketiga, Relevansi Konsep Kesetaraan Laki-Laki dan Perempuan (Suami dan Istri) dengan Pokok-Pokok Pembaharuan di bidang Keluarga, yaitu, Prinsip egaliter, menanamkan adanya persamaan antar manusia, baik laki-laki maupun perempuan. Secara teoritis al-Quran dan hadis mengandungn prinsip kesetaran antara laki-laki dan perempuan, ini dapat dilihat dalam QS. alHujuraat : 13. Islam mengubah sistem patriarki dengan memberikan hak yang sama dalam sistem waris serta kedudukan yang mulia dalam pernikahan. Islam sangat menekankan prinsip kesetaraan antara perempuan dan laki-laki (suami dan istri), sehingga keberlakuan tradisi perkawinan pra-Islam dirombak dan diubah oleh syariat Islam, hal ini sejalan dengan tuntutan egaliter laki-laki dan perempuan karena Islam sejatinya menghormati dan menghargai kedudukan laki-laki dan perempuan. 
TAHKIM, Jurnal Peradaban dan Hukum Islam. Vol.4 No.l (Maret, 202I) | ISSN : 2597-7962

\section{DAFTAR PUSTAKA}

\section{Buku}

Akbar S. Ahmed. (2002). Rekonstruksi Sejarah Islam, Yogyakarta: Fajar Pustaka Baru.

Bustami, Muhammad Said. (1995). Gerakan Pembaharuan Agama Antara Modernisme dan Tajdiduddin, Bekasi: Wacana Lajuardi.

Departemen Agama RI. (2015). Al-Quran dan terjemah, Bandung:CV Darus Sunnah.

Husain, Muhammad. (2003). Sejarah Hidup Muhammad. Jakarta: Tintamas.

Moleong, Lexi J. (2002). Metode Penelitian Kualitatif, Bandung: PT. Remaja Rosda Karya.

Murteza M. Mutahhari. (1985). Wanita dan Hak-haknya dalam Islam, Terj, Hashem, Bandnung: Pustaka.

Suhali Sufyan, Muhammad. (2012). Fiqih Mawaris Praktis, Bandung: Cipta Pustaka Media Perintis.

\section{Jurnal :}

Arzam. (2014). Hukum Islam Sebagai Revolusioner dan Egaliter dalam Kehidupan Sosial. Islamika, Vol. 14, No. 1. Juni. 1-15.

Asrizal. (2016). Peletakan Dasar-Dasar Hukum Kewarisan Islam (Tinjaun Historis atas Hukum Waris Pra dan Awal Islam). Al-Ahwal, Vol. 9, No.1. 125-137.

Fauzi, Fahrul. (2020). Larangan Perkawinan Sepersusuan Ditinjau dari Perspektif Hukum Islam dan Medis. Tahkim: Jurnal Peradaban dan Hukum Islam, Vol. 3, No. 2. $39-58$.

Haris, Munawir. (2015). Pembaharuan atas Hukum Keluarga di Indonesia: Satu Tinjauan Sosiologis. Ulumuna, Vol. 19, No. 1. June. 137-158.

Hasibuan, Nia Kurniati. (2020). Implementasi Hukum Waris pada Masyarakat Adat Mandailing Perantauan (Studi pada Pardomuan Muslim Sumatera Utara Kota Palangka Raya). Tahkim: Jurnal Peradaban dan Hukum Islam, Vol. 3, No. 2, 115-130. 
TAHKIM, Jurnal Peradaban dan Hukum Islam. Vol.4 No.1 (Maret, 2021) | ISSN : 2597-7962

Hermawan, A. Hendri dkk. (2018). Kewenangan dan Kedudukan Perempuan dalam Perspektif Gender: Suatu Analisis Tinjauan Historis. Marwah, Vol. 17, No. 1. 43-62.

Kamadi, Dahar. (2013). Rustam. Kesetaraan laki-laki dan perempuan dalam Hukum Perkawinan Islam. Sawwa, Vol. 8, No. 2, April. 363-383.

Rahim Amin, Abd. (2012). Hukum Islam dan Transformasi Sosial Masyarakat Jahiliyyah: (Studi Historis tentang Karakter Egaliter Hukum Islam). Jurnal Hukum Diktum, Vol. 10, No. 1. 2-10.

Romziyana, Luthviyah. (2014). Pandangan al-Qur'an Tentang Makna jahiliyah Perspektif Semantik. Mutawatir: Jurnal Keilmuan Tafsir Hadis, Vol. 4, No. 1, 118-138.

Wahyuni, Sri. (2013). PembaharuanHukum Keluarga Islam di Negara-Negara Muslim. Al-ahwal, Vol. 6, No. 2. 211-219.

Zuhra, Fatimah. (2013). Relasi Suami dan Istri dalam Keluarga Muslim Menurut Konsep Al-Quran. Analytica Islamimica, Vol. 2, No. 1.178-192.

\section{Web}

$A b u$ Hapsin, "Islam dan Budaya Lokal: Ketegangan antara Problem Pendekatan dan Kearifan Lokal Masyarakat Jawa", dalam http//www/kemenag,go.idacisl filedokumene2AbuHapsin.pdf.

Zainal, Asliah, Egaliter Laki-laki dan Perempuan dalam Keluarga Islam: Antara Idealis dan Realitas. STAIN Sultan Qaimudddin Kendari dalam da.ristekdikti.go. 
TAHKIM, Jurnal Peradaban dan Hukum Islam. Vol.4 No.l (Maret, 202I) | ISSI : 2597-7962 